\title{
Amino Acid Sequence Analysis of Ribosomal Protein AT-L30 from Members of the Family Pseudonocardiaceae
}

\author{
$\mathrm{KOZO}_{\mathrm{OCHI}}^{*}$ \\ National Food Research Institute, 2-1-2 Kannondai, Tsukuba, Ibaraki 305, Japan
}

\begin{abstract}
The phylogenetic relationships of the genera belonging to the family Pseudonocardiaceae were examined by a novel approach, amino acid sequencing of ribosomal AT-L30 proteins. The results of partial amino acid sequencing of AT-L30 preparations revealed that the members of the family Pseudonocardiaceae are divided into four clusters; the first cluster contains the genus Actinopolyspora, the second cluster contains the genus Saccharopolyspora, the third cluster contains the genus Amycolatopsis, and the fourth cluster contains the genera Amycolata, Pseudonocardia, Saccharomonospora, and Kibdelosporangium, indicating a close phylogenetic relationship between the genera Amycolata and Pseudonocardia. The genus Actinokineospora is closely related to the genus Saccharothrix, and these two genera formed a cluster separate from the clusters for the genera of the Pseudonocardiaceae. These results agree in almost all respects with previous 16S rRNA sequencing work by Embley et al. (T. M. Embley, J. Smida, and E. Stackebrandt, Syst. Appl. Microbiol. 11:44-52, 1988) and Warwick et al. (S. Warwick, T. Bowen, H. McVeigh, and T. M. Embley, Int. J. Syst. Bacteriol. 44:293-299, 1994), thus supporting the proposal of Warwick et al. that the genera Amycolata and Pseudonocardia should be combined in an emended genus, Pseudonocardia. However, a discrepancy was found between the present study and that of Warwick et al. In the present study, the Nocardia-Rhodococcus group and the SaccharothrixActinokineospora group were both recovered within the clade for the family Pseudonocardiaceae.
\end{abstract}

The wall chemotype IV actinomycetes are a group of actinomycetes which contain meso-diaminopimelic acid, arabinose, and galactose in their cell walls and can be divided into at least two groups based on the presence or absence of mycolic acids. Members of the genera Conynebacterium, Mycobacterium, Nocardia, and Rhodococcus, classified in a group, contain mycolic acids (reviewed by Goodfellow and Cross [11]). Another group, which includes the genera Pseudonocardia (which replaces Amycolata), Actinopolyspora, Amycolatopsis, Saccharomonospora, and Saccharopolyspora, is characterized by the absence of mycolic acids (reviewed by Lechevalier [22]), and the members of the group share a number of chemotaxonomic features with each other $(3,5,6,9,10,14,20$, 24). Therefore, on the basis of $16 \mathrm{~S}$ rRNA sequence analysis, together with such chemotaxonomic similarity, Embley et al. (8) proposed an amended family, Pseudonocardiaceae, for the mycolateless wall chemotype IV actinomycetes. Subsequently, on the basis of the results of 16S rRNA sequence analysis, Bowen et al. $(1,2)$ proposed that the genera Amycolata and Kibdelosporangium should also be included in this family. The family Pseudonocardiaceae contains a number of economically important organisms, including the producers of erythromycin, rifamycin, and vancomycin (4). All current members of the family have been reported to have a chemotype IV cell wall $(21,23)$. The genus Actinokineospora was proposed by Hasegawa (13) for a new genus with a mycolateless chemotype IV cell wall. The genus Saccharothrix, originally thought to be closely related to the genus Nocardiopsis on the basis of morphology (21), has been shown to be related to members of the family Pseudonocardiaceae on the basis of chemotaxonomic and $16 \mathrm{~S}$ rRNA sequence results (1). However, unlike members of the family Pseudonocardiaceae, Saccharothrix strains have chemotype III walls (21). For this reason, it was deemed premature to transfer the genus Saccharothrix to the family Pseudonocardiaceae (1). The phylogenetic position of these actinomycetes with mycolateless chemotype IV or III cell walls

* Phone: 0298-38-8125. Fax: 0298-38-7996. was investigated by using reverse transcriptase sequencing of $16 \mathrm{~S}$ rRNA $(1,7,8)$. The most recent study by Warwick et al. (38) demonstrated that the genera Amycolata and Pseudonocardia are always recovered as a mixed group in phylogenetic trees. Accordingly, they proposed that these genera should be reclassified in an emended genus Pseudonocardia. (In this paper, for convenience, we use the name Amycolata instead of the unified name Pseudonocardia.) On the other hand, the phylogenetic branching pattern did not unambiguously resolve whether the members of the genera Saccharothrix and Actinokineospora should be placed in the family Pseudonocardiaceae (38). Therefore, these two genera will remain outside the family Pseudonocardiaceae until additional data become available to decide the issue.

I have recently used ribosomal protein analysis to investigate the taxonomy of actinomycetes and developed a novel method for classification and identification $(26,28)$, based on the heterogeneity of ribosomal proteins. While there is striking variability in the electrophoretic mobilities of ribosomal ATL30 proteins among genera of actinomycetes, these proteins exhibit electrophoretic mobilities that are specific for each genus $(27,32,33)$. On the basis of this observation, Ochi and Yoshida (35) analyzed the AT-L30 proteins of members of the family Pseudonocardiaceae by using two-dimensional polyacrylamide gel electrophoresis (PAGE) and demonstrated that the genera Actinopolyspora, Saccharopolyspora, Amycolatopsis, Pseudonocardia, and Saccharomonospora can be distinguished by the electrophoretic properties of the AT-L30 proteins. Subsequently, Ochi et al. $(30,34)$ also found that amino acid sequence analysis of the AT-L30 proteins, together with electrophoretic analysis, can be a useful basis for classification at the genus level. The aim of this study was to review the family Pseudonocardiaceae by using our amino acid sequence analysis method.

\section{MATERIALS AND METHODS}

Bacterial strains. The strains used in this study are listed in Table 1. Almost all were type strains obtained from the Japan Collection of Microorganisms, 
TABLE 1. Strains used in this study and REM values of ribosomal AT-L30 proteins

\begin{tabular}{|c|c|c|}
\hline Species $^{a}$ & Strain designation & REM $^{b}$ \\
\hline Actinopolyspora halophila & $\operatorname{ATCC} 27976^{\mathrm{T}}$ & $46.0^{\circ}$ \\
\hline Actinopolyspora mortivallis & JCM $7550^{\mathrm{T}}\left(\mathrm{ATCC} 49777^{\mathrm{T}}\right)$ & $42.5^{c}$ \\
\hline Saccharopolyspora hirsuta subsp. hirsuta & JCM $3170^{\mathrm{T}}\left(\right.$ ATCC $\left.27875^{\mathrm{T}}\right)$ & $66.5^{c}$ \\
\hline Saccharopolyspora rectivirgula & JCM $3057^{\mathrm{T}}\left(\operatorname{ATCC} 33515^{\mathrm{T}}\right)$ & $67.0^{c}$ \\
\hline Amycolatopsis azurea & $\mathrm{JCM} 3275^{\mathrm{T}}\left(\mathrm{DSM} 43854^{\mathrm{T}}\right)$ & $73.0^{\circ}$ \\
\hline Amycolatopsis orientalis subsp. orientalis & JCM $4600^{\mathrm{T}}\left(\right.$ ATCC $\left.19795^{\mathrm{T}}\right)$ & $71.0^{\circ}$ \\
\hline Amycolatopsis fastidiosa & JCM $3276^{\mathrm{T}}\left(\right.$ ATCC $\left.31181^{\mathrm{T}}\right)$ & 68.0 \\
\hline Amycolata autotrophica (Pseudonocardia autotrophica) & JCM $4348^{\mathrm{T}}\left(\right.$ ATCC $\left.19727^{\mathrm{T}}\right)$ & $81.0^{c}$ \\
\hline Amycolata saturnea (Pseudonocardia satumea) & JCM $3187^{\mathrm{T}}\left(\right.$ ATCC $\left.15809^{\mathrm{T}}\right)$ & $\mathrm{ND}^{d}$ \\
\hline Amycolata hydrocarboxydans (Pseudonocardia hydrocarboxydans) & $\operatorname{JCM~} 3392^{\mathrm{T}}\left(\right.$ ATCC $\left.15104^{\mathrm{T}}\right)$ & $88.5^{c}$ \\
\hline Pseudonocardia thermophila & JCM $3095^{\mathrm{T}}\left(\right.$ ATCC $\left.19285^{\mathrm{T}}\right)$ & $86.0^{c}$ \\
\hline Saccharomonospora glauca & $\mathrm{JCM} 7444^{\mathrm{T}}\left(\mathrm{DSM} 43769^{\mathrm{T}}\right)$ & $98.0^{c}$ \\
\hline Saccharomonospora caesia & JCM $3098^{\mathrm{T}}\left(\mathrm{DSM} 43044^{\mathrm{T}}\right)$ & 96.0 \\
\hline Saccharomonospora viridis & JCM $3036^{\mathrm{T}}\left(\right.$ ATCC $\left.15386^{\mathrm{T}}\right)$ & $100^{c}$ \\
\hline Actinokineospora riparia & JCM $7471^{\mathrm{T}}\left(\right.$ ATCC $\left.49499^{\mathrm{T}}\right)$ & 28.0 \\
\hline Saccharothrix australiensis & JCM $3370^{\mathrm{T}}\left(\right.$ ATCC $\left.31497^{\mathrm{T}}\right)$ & 70.0 \\
\hline Saccharothrix aerocolonigenes & $\mathrm{JCM} 4614^{\mathrm{T}}\left(\mathrm{ATCC} 23870^{\mathrm{T}}\right)$ & 65.0 \\
\hline Saccharothrix mutabilis subsp. mutabilis & JCM $3380^{\mathrm{T}}\left(\right.$ ATCC $\left.31520^{\mathrm{T}}\right)$ & 71.0 \\
\hline Kibdelosporangium aridum & ATCC $39323^{\mathrm{T}}$ & $41.5^{c}$ \\
\hline Rhodococcus rhodochrous & $\mathrm{JCM} 3202^{\mathrm{T}}\left(\mathrm{ATCC} 13808^{\mathrm{T}}\right)$ & 47.5 \\
\hline Mycobacterium diernhoferi & JCM $6371^{\mathrm{T}}\left(\right.$ ATCC $\left.19340^{\mathrm{T}}\right)$ & ND \\
\hline Corynebacterium diphtheriae & JCM 1310 (ATCC 11913) & ND \\
\hline Nocardia asteroides & JCM $3384^{\mathrm{T}}\left(\right.$ ATCC $\left.19247^{\mathrm{T}}\right)$ & 59.0 \\
\hline Streptomyces parvulus & ATCC $12434^{\mathrm{T}}$ & $17.0^{c}$ \\
\hline
\end{tabular}

${ }^{a}$ The names in parentheses are emended names.

${ }^{b}$ The electrophoretic mobilities (in the first dimension) of the AT-L30 proteins are expressed as REMs compared with the electrophoretic mobility of the Saccharomonospora viridis AT-L30 protein. The mobility of protein AT-L30 from Saccharomonospora viridis JCM $3036^{\mathbf{T}}$ was defined as unity (100).

${ }^{c}$ Data from references $27,32,34$, and 35.

${ }^{d} \mathrm{ND}$, not determined.

Wako-shi, Saitama, Japan, and the American Type Culture Collection, Rockville, Md. Actinopolyspora mortivallis $\mathrm{JCM} 7550^{\mathrm{T}}(\mathrm{T}=$ type strain) is a strain which was proposed recently as a new species (40), and Actinokineospora riparia JCM $7471^{\mathrm{T}}$ is a strain which was proposed as a new species representing a new genus (13).

Preparation of total ribosomal proteins. The halophilic bacteria, Actinopolyspora halophila and Actinopolyspora mortivallis, were grown in a medium containing $20 \%$ (wt/vol) $\mathrm{NaCl}$ as previously described (35). Other strains (Table 1) were grown in soluble starch-polypeptone-yeast extract medium at $30^{\circ} \mathrm{C}$ as previously described (33), except for Pseudonocardia thermophila, which was grown at $55^{\circ} \mathrm{C}$. Ribosomal proteins were prepared from $70 S$ ribosomes by extraction with acetic acid, as previously described (26), by the method of Hardy et al. (12). The total ribosomal protein samples obtained in this way contained 20 to $30 \mathrm{mg}$ of protein per ml.

Two-dimensional PAGE. Two-dimensional PAGE by the method of Kaltschmidt and Wittmann (17) has been described in detail previously (26). After each slab gel was stained with Coomassie blue, the AT-L30 protein spot was identified. The electrophoretic mobilities (in the first dimension) of the AT-L30 proteins were expressed as relative electrophoretic mobilities (REMs) compared with the electrophoretic mobility of the Saccharomonospora viridis AT-L30 protein, which exhibited the greatest mobility of all of the actinomycete AT-L30 proteins examined (27). The amounts of the total ribosomal proteins applied to the PAGE gels for the purpose of REM determination were 400 to $500 \mu \mathrm{g}$. However, 5 to $10 \mathrm{mg}$ of the total ribosomal proteins were used when preparing the AT-L30 protein sample for amino acid sequence analysis.

Determination of amino acid sequence. After two-dimensional PAGE, the proteins were extracted from the gels and used for amino acid sequence analysis as previously described (31). Determination of a maximum of $26 \mathrm{~N}$-terminal amino acids was possible when about $150 \mathrm{pmol}$ (corresponding to about $1.5 \mu \mathrm{g}$ ) of AT-L30 preparation was analyzed.

\section{RESULTS}

Two-dimensional PAGE analysis of ribosomal proteins. The ribosomal proteins from more than 20 species belonging to the genera of the family Pseudonocardiaceae and related genera (Table 1) were studied. Table 1 shows that species belonging to the same genus exhibited similar electrophoretic properties of AT-L30 proteins as expressed by REMs. In contrast, each genus displayed REMs that were distinct from those of other genera. The only exception was Pseudonocardia thermophila (the type species of the genus Pseudonocardia), with an REM of 86.0, which overlapped with that of the genus Amycolata (REMs, 81.0 to 88.5). I attempted to analyze another Pseudonocardia species, Pseudonocardia compacta (15), but it was too difficult to prepare ribosomal proteins from this species, perhaps because of its extremely slow growth. Therefore, this organism was not included in the present study. Actinokineospora riparia had a low REM value (28.0) that was clearly distinct from those of other genera, supporting the taxonomic status of this organism in a new genus. Although these results provided additional evidence that actinomycete taxa of the mycolateless wall chemotype IV should be classified as distinct genera, I further analyzed these organisms by sequencing the $\mathrm{N}$-terminal amino acids of the AT-L30 proteins.

Amino acid sequences of AT-L30 proteins. The AT-L30 proteins from members of the family Pseudonocardiaceae were subjected to amino acid sequence analysis, and the results are presented in Fig. 1. The members of the mycolic acid-containing genera Nocardia, Rhodococcus, Corynebacterium, and Mycobacterium were also analyzed for reference. It is immediately evident from Fig. 1 that species belonging to the same genus displayed sequences with a high level of homology. There were 16 variable positions within the $20 \mathrm{~N}$-terminal amino acids among the members of the family Pseudonocardiaceae. To express quantitatively the levels of similarity of the amino acid sequences (SAS values), I determined the frequency of appearance of a particular amino acid in $20 \mathrm{~N}$-terminal amino acids of each AT-L30 protein. Smaller numbers of amino acids were compared in several combinations. Nondetermined positions were not weighted for the calculation of SAS values. The SAS values determined in this way for every combination of strains tested are shown in Table 2. High SAS values (84 to 94\%) were detected within the genera Actinopolyspora, Saccharopolyspora, 


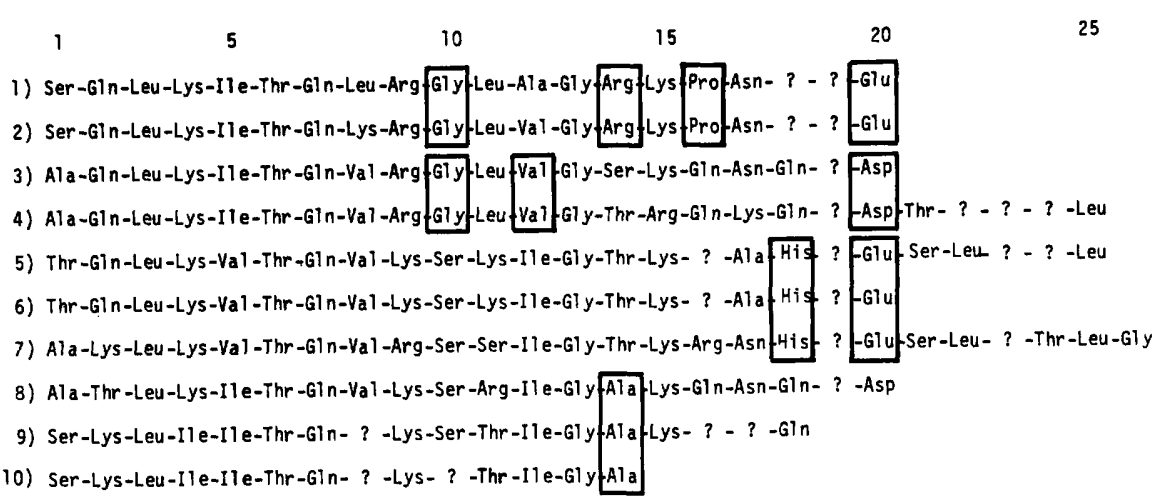

11) Ala-Lys-Leu-Lys-Ile-Thr-Gln-Il e-Lys-Ser-Thr-Il e-G1 y-Gly-Lys-Asp-Tyr-Gln- ? -Ala-Thr-Ile- ? - ? -Leu

12) Ala-Gln-Leu-Lys-Il e-Thr-Gln-Thr-Lys-Ser-Thr-Ile-Gly-? -Lys-Gln-Asn-Gln- ? Ala

13) Ala-Gln-Leu-Lys-I le-Thr-Gln-Ile-Lys-Ser-Thr-Ile-Gly-Thr-Lys-Gln-Asn - ? - ? -Ala

14) Ala-Gln-Leu-Lys-Ile-Thr-Gln-Thr-Lys-Ser-Thr-Il e-Gly-Thr-Lys-Gln-Ala-Gln- ? -Ala

15) Ala-Lys -Leu-Lys -Val -Thr-Gln-Val -Arg-Ser Glu I l e-Gly-Thr-Lys-Arg-Asn Ala Arg-Glu-Ser-Leu - ? -Thr-Leu-Gly

16) Ala-Arg-Leu-Lys-Il e-Thr-Gln-Thr-Lys-Ser-Tyr-Ile-Gly-Ser-Lys-Gln-Asn His ? -Asp-Thr-Leu- ? -Ser-Leu-Gly

17) Ala-----Leu-Lys-Il e-Thr-GIn-Val-Arg-Ser-Thr-Il e-Gly-Thr-Lys - ? -Asn ? Arg-Glu-Ser - ? - ? -Thr-Leu-Gly

18) Ala-Gln-Leu-Lys-Val-Thr-GIn-Val-Lys-Ser-His-Ile-Gly-Thr-Lys-? -Asn. His.? -Glu-Ser-Leu- ? -Thr-Leu-Gly

19) Ala-Lys-Leu Gln Il e-Thr-Gln-Val-Lys-Ser-Lys-Il e-Gly-Thr-Lys-? -Asn-? -Arg-Glu-Ser-Leu - ? -Thr-Leu-Gly

20) Ala-GIu-Leu-Lys-Ile-Thr-Gln-Ile-Lys-Ser-Thr-Ile-Gly-Ala-Lys-Ser-Asn-Gln- ? -Asp

21) Ala-Glu-Leu-Lys-I le-Thr-Gln-Val-Arg-Gly-Thr-Ile-Gly-Ala-Arg- ? -Lys-Gln- ? -Glu

22) Ala-----Leu-Lys-Ile-Thr-Gln-His-Lys-Gl y-Leu-Val -Gl y-Ala-Asn-Pro-Lys-Gln- ? - ? -Asn

23) Ala-Asp-Leu-Lys-Val-Thr-Gin-Il e-Lys-Ser-Thr-I le-Gi y-Ala-Lys-Ala-Asn-Gin-Lys-Asp-Ser-Leu

24) 41 a-Gln-Leu-Lys-Ile-Thr-Gln-Val-Lys-Ser-Tyr-Ile-Gly-Ser-Lys-Gln-Asn - ? - ? -Asp-Thr-Leu - ? -Ser-Leu

25) Ala-Lys-Thr-Il e-Lys-Il e-Thr-Gln-Thr-Arg-Ser-Ala-Ile-Gl y-Arg-Leu-Pro-Lys-His -Lys-Ala -Thr -Leu-Leu-Gl y-Leu

26) Ala-Lys-Lys-Leu-Ala-Il e-Thr-Leu-Thr-Arg-Ser-Val-Ile-Gl y-Arg-Pro-Glu-Asp-Gln-Arg-Ile-Thr-Val-Arg-Thr-Leu

FIG. 1. Primary structures of N termini of AT-L30 proteins from various species of the genera belonging to or closely related to the family Pseudonocardiaceae. The data for Escherichia coli and Bacillus stearothermophilus are from references 36 and 18, respectively. Question marks indicate amino acids that were not determined. The dotted lines indicate deletions. The amino acids which characterize each genus are boxed. Lines: 1, Actinopolyspora halophila; 2, Actinopolyspora mortivallis; 3 , Saccharopolyspora hirsuta subsp. hirsuta; 4, Saccharopolyspora rectivirgula; 5, Amycolatopsis azurea; 6, Amycolatopsis orientalis subsp. orientalis; 7, Amycolatopsis fastidiosa; 8, Amycolata autotrophica; 9, Amycolata saturnea; 10, Amycolata hydrocarboxydans; 11, Pseudonocardia thermophila; 12, Saccharomonospora glauca; 13, Saccharomonospora caesia; 14, Saccharomonospora viridis; 15, Actinokineospora riparia; 16, Saccharothrix australiensis; 17, Saccharothrix aerocolonigenes; 18, Saccharothrix mutabilis subsp. mutabilis; 19, Kibdelosporangium aridum; 20, Rhodococcus rhodochrous; 21, Mycobacterium diernhoferi; 22, Corynebacterium diphtheriae; 23, Nocardia asteroides; 24, Streptomyces parvulus; 25, Escherichia coli K-12; 26, Bacillus stearothermophilus NCA 1503.

and Saccharomonospora. In contrast, low SAS values (65 to $76 \%$ ) were detected within the genus Saccharothrix.

On the basis of SAS values presented in Table 2, I constructed a dendrogram (Fig. 2). The genera Nocardia, Rhodococcus, Mycobacterium, and Corynebacterium were included in the dendrogram for reference. As Fig. 2 shows, 15 species of the genera in the Pseudonocardiaceae formed separate lines from the mycolic acid-containing genera Mycobacterium and Corynebacterium and were divided into four clusters; the first contained the genus Actinopolyspora, the second contained the genus Saccharopolyspora, the third contained the genus Amycolatopsis, and the fourth contained the genera Amycolata, Pseudonocardia, Saccharomonospora, and Kibdelosporangium. Surprisingly, Nocardia asteroides and Rhodococcus rhodochrous were recovered within the clade that includes the family Pseudonocardiaceae, exhibiting a close relationship with the genera Pseudonocardia and Amycolata. Similarly, the members of the wall chemotype III genus Saccharothrix and the wall chemotype IV genus Actinokineospora were also recovered within the clade for the family Pseudonocardiaceae, but these two genera were more clearly distinguished from the clusters for the genera of the family Pseudonocardiaceae (Fig. 2).

Characteristics of amino acid sequences. In addition to simple comparison on the homology level of amino acid sequences of AT-L30 proteins, we have recently found that it is possible to pinpoint amino acids located at specific positions which characterize each genus $(29,31)$. Amino acids which characterize each genus are indicated by boxes in Fig. 1. The genus Actinokineospora is characterized by glutamic acid at position 11 and alanine at position 18 .

\section{DISCUSSION}

In a previous study, Ochi and Yoshida (35) created a sound basis for PAGE data for the family Pseudonocardiaceae. The observed electrophoretic heterogeneity of AT-L30 proteins within the family reflected the results of investigations of $16 \mathrm{~S}$ rRNA analysis by Bowen et al. (1) and Embley et al. $(7,8)$. In the present study, I confirmed our previous conclusion by using another approach: amino acid sequence analysis of AT-L30 proteins. Although previously the genera Amycolatopsis and Saccharopolyspora were not distinguished from each other with respect to REM values (35), the present study demonstrated clearly that these genera are separable at the genus level (Fig. 2). In the dendrogram (Fig. 2), the genera Actinopolyspora and Saccharopolyspora exhibited deep branching from other mem- 
TABLE 2. SAS values for the amino acid sequences of AT-L30 proteins ${ }^{a}$

\begin{tabular}{|c|c|c|c|c|c|c|c|c|c|c|c|c|c|c|c|c|c|c|c|c|c|c|c|}
\hline \multirow{2}{*}{ Species } & \multicolumn{23}{|c|}{ SAS value $(\%)$} \\
\hline & 1 & 2 & 3 & 4 & 5 & 6 & 7 & 8 & 9 & 10 & 11 & 12 & 13 & 14 & 15 & 16 & 17 & 18 & 19 & 20 & 21 & 22 & 23 \\
\hline 1. Actinopolyspora halophila & - & & & & & & & & & & & & & & & & & & & & & & \\
\hline 2. Actinopolyspora mortivallis & 89 & - & & & & & & & & & & & & & & & & & & & & & \\
\hline 3. Saccharopolyspora hirsuta & 67 & 72 & - & & & & & & & & & & & & & & & & & & & & \\
\hline 4. Saccharopolyspora rectivirgula & 56 & 61 & 84 & - & & & & & & & & & & & & & & & & & & & \\
\hline 5. Amycolatopsis azurea & 47 & 47 & 44 & 44 & - & & & & & & & & & & & & & & & & & & \\
\hline 6. Amycolatopsis orientalis & 47 & 47 & 44 & 44 & 100 & - & & & & & & & & & & & & & & & & & \\
\hline 7. Amycolatopsis fastidiosa & 50 & 50 & 53 & 47 & 72 & 72 & - & & & & & & & & & & & & & & & & \\
\hline 8. Amycolata autotrophica & 44 & 44 & 68 & 58 & 56 & 56 & 58 & - & & & & & & & & & & & & & & & \\
\hline 9. Amycolata saturnea & 50 & 50 & 47 & 40 & 53 & 53 & 53 & 73 & - & & & & & & & & & & & & & & \\
\hline 10. Amycolata hydrocarboxydans & 55 & 55 & 45 & 45 & 55 & 55 & 55 & 73 & 100 & - & & & & & & & & & & & & & \\
\hline 11. Pseudonocardia thermophila & 39 & 39 & 47 & 42 & 50 & 50 & 53 & 63 & 80 & 73 & - & & & & & & & & & & & & \\
\hline 12. Saccharomonospora glauca & 53 & 53 & 67 & 56 & 59 & 59 & 56 & 78 & 79 & 70 & 78 & - & & & & & & & & & & & \\
\hline 13. Saccharomonospora caesia & 50 & 50 & 61 & 56 & 65 & 65 & 61 & 72 & 71 & 64 & 78 & 94 & - & & & & & & & & & & \\
\hline 14. Saccharomonospora viridis & 44 & 44 & 58 & 58 & 67 & 67 & 53 & 68 & 73 & 64 & 74 & 94 & 89 & - & & & & & & & & & \\
\hline 15. Actinokineospora riparia & 50 & 50 & 53 & 47 & 67 & 67 & 89 & 58 & 53 & 55 & 53 & 56 & 61 & 53 & - & & & & & & & & \\
\hline 16. Saccharothrix australiensis & 44 & 44 & 63 & 47 & 56 & 56 & 58 & 74 & 60 & 64 & 58 & 78 & 72 & 68 & 53 & - & & & & & & & \\
\hline 17. Saccharothrix aerocolonigenes & 59 & 59 & 65 & 59 & 65 & 65 & 82 & 71 & 64 & 55 & 65 & 75 & 76 & 71 & 83 & 65 & - & & & & & & \\
\hline 18. Saccharothrix mutabilis & 53 & 53 & 56 & 50 & 83 & 83 & 78 & 67 & 53 & 55 & 56 & 71 & 76 & 67 & 78 & 67 & 76 & - & & & & & \\
\hline 19. Kibdelosporangium aridum & 47 & 47 & 53 & 47 & 71 & 71 & 76 & 71 & 71 & 73 & 65 & 69 & 71 & 65 & 78 & 65 & 78 & 76 & - & & & & \\
\hline 20. Rhodococcus rhodochrous & 44 & 44 & 58 & 47 & 50 & 50 & 53 & 79 & 80 & 73 & 74 & 78 & 78 & 68 & 53 & 68 & 71 & 61 & 65 & - & & & \\
\hline 21. Mycobacterium diemhoferi & 53 & 53 & 61 & 72 & 44 & 44 & 56 & 61 & 60 & 64 & 56 & 59 & 53 & 56 & 56 & 44 & 71 & 50 & 53 & 67 & - & & \\
\hline 22. Corynebacterium diphtheriae & 53 & 59 & 61 & 67 & 35 & 35 & 33 & 56 & 53 & 64 & 50 & 53 & 47 & 50 & 33 & 44 & 47 & 41 & 44 & 56 & 65 & - & \\
\hline 23. Nocardia asteroides & 39 & 39 & 53 & 42 & 56 & 56 & 58 & 74 & 73 & 64 & 68 & 72 & 72 & 63 & 55 & 63 & 61 & 67 & 56 & 84 & 56 & 50 & \\
\hline 24. Streptomyces parvulus & 50 & 50 & 79 & 63 & 61 & 61 & 58 & 84 & 67 & 64 & 63 & 83 & 78 & 74 & 58 & 84 & 71 & 72 & 71 & 74 & 56 & 50 & 68 \\
\hline
\end{tabular}

${ }^{a}$ The SAS values for each pair of organisms for $20 \mathrm{~N}$-terminal amino acids (but a smaller number of amino acids in several combinations) of the AT-L30 proteins were determined on the basis of the data shown in Fig. 1. Undetermined positions were not weighted for the calculation of SAS values.

bers of the family Pseudonocardiaceae. On the other hand, the genera Amycolata, Pseudonocardia, and Kibdelosporangium formed coherent lines. These results are entirely in agreement with the previous work on rRNA sequencing analysis by Warwick et al. (38) and Bowen et al. (1). In the work of Warwick et al. (38), the strains examined were classified into three groups on the basis of $16 \mathrm{~S}$ rRNA sequence data: the first contained the Actinoplanetes group, comprising the genera Micromonospora, Ampullariella, and Dactyrosporangium; the second contained the mycolic acid-containing wall chemotype IV taxa such as Nocardia, Rhodococcus, Mycobacterium, and Corynebacterium; and the third contained the genera Saccharothrix, Actinokineospora, and members of the family Pseudonocardiaceae. However, the branching order for these three groups was unstable and varied with the choice of outgroup taxa and the method of analysis (38). In this respect, there is a significant discrepancy between my AT-L30 work and that of Warwick et al. (38), namely, that in my study both the Nocardia-Rhodococcus cluster and the Saccharothrix-Actinokineospora cluster were recovered as a sister group within a clade of the family Pseudonocardiaceae (Fig. 2), while in the study of Warwick et al. (38) these genera were recovered in clades outside the family Pseudonocardiaceae. No explanation can be offered at this time, but the work of Warwick et al. (38) explains the classification of mycolic acid-containing and nonmycolic acid-containing groups better. On the basis of my AT-L30 work (Fig. 2), it is possible that the members of the family Pseudonocardiaceae evolved from a common ancestor, with a loss of mycolic acid, in the process of development to the Nocardia-Rhodococcus group. In the light of this notion, the Saccharothrix-Actinokineospora group, another taxon without mycolic acid, may be taken as a member of the family Pseudonocardiaceae. These issues remain to be clarified. Another discrepancy found between our AT-L30 analysis and 16S rRNA analysis was that in the former method the genus
Saccharomonospora was closely related to the genera Pseudonocardia and Amycolata (with respect to both REM value and amino acid sequence homology), while in the latter method it exhibited a close relationship to the genus Amycolatopsis.

The genus Saccharothrix was proposed by Labeda et al. (21) for a single isolate containing a chemotype III wall. Actinokineospora riparia, a new genus proposed by Hasegawa (13), has chemotype IV walls. Despite their difference in wall chemotypes, these two taxa were closely related (Fig. 2). The close phylogenetic relatedness of the genera Actinokineospora and Saccharothrix was also reported by Warwick et al. (38) on the basis of 16S rRNA sequence analysis. Recent investigations by Takeuchi et al. (37) showed that the cell wall of the genus Actinokineospora (and also of the genera Amycolatopsis, Kibdelosporangium, Pseudonocardia, and Saccharomonospora) was chemotype III, displaying meso-diaminopimelic acid in the peptidoglycan and galactose among the whole-cell sugars, while the content of arabinose was very low. However, since the location and amount of arabinose may vary significantly among members of the family Pseudonocardiaceae $(4,31)$, it is deemed that the distinction between wall chemotype IV and wall chemotype III among members of the family may not be as taxonomically significant as was once thought $(1,4,38)$. The taxonomic status of the genus Actinokineospora as a distinct genus is, however, emphasized by the marked difference in REM values between Actinokineospora riparia (REM, 28.0) and the genus Saccharothrix (REMs, 65.0 to 71.0) (Table 1). In the study by Warwick et al. (38), the phylogenetic branching pattern did not unambiguously resolve whether the members of the genera Actinokineospora and Saccharothrix should be placed in the family Pseudonocardiaceae. My results of AT-L30 protein analyses also did not resolve this issue (Fig. 2). High SAS values detected within genera indicate that species within those genera are closely related to each other. Low SAS values between genera indicate their differences from each other. 


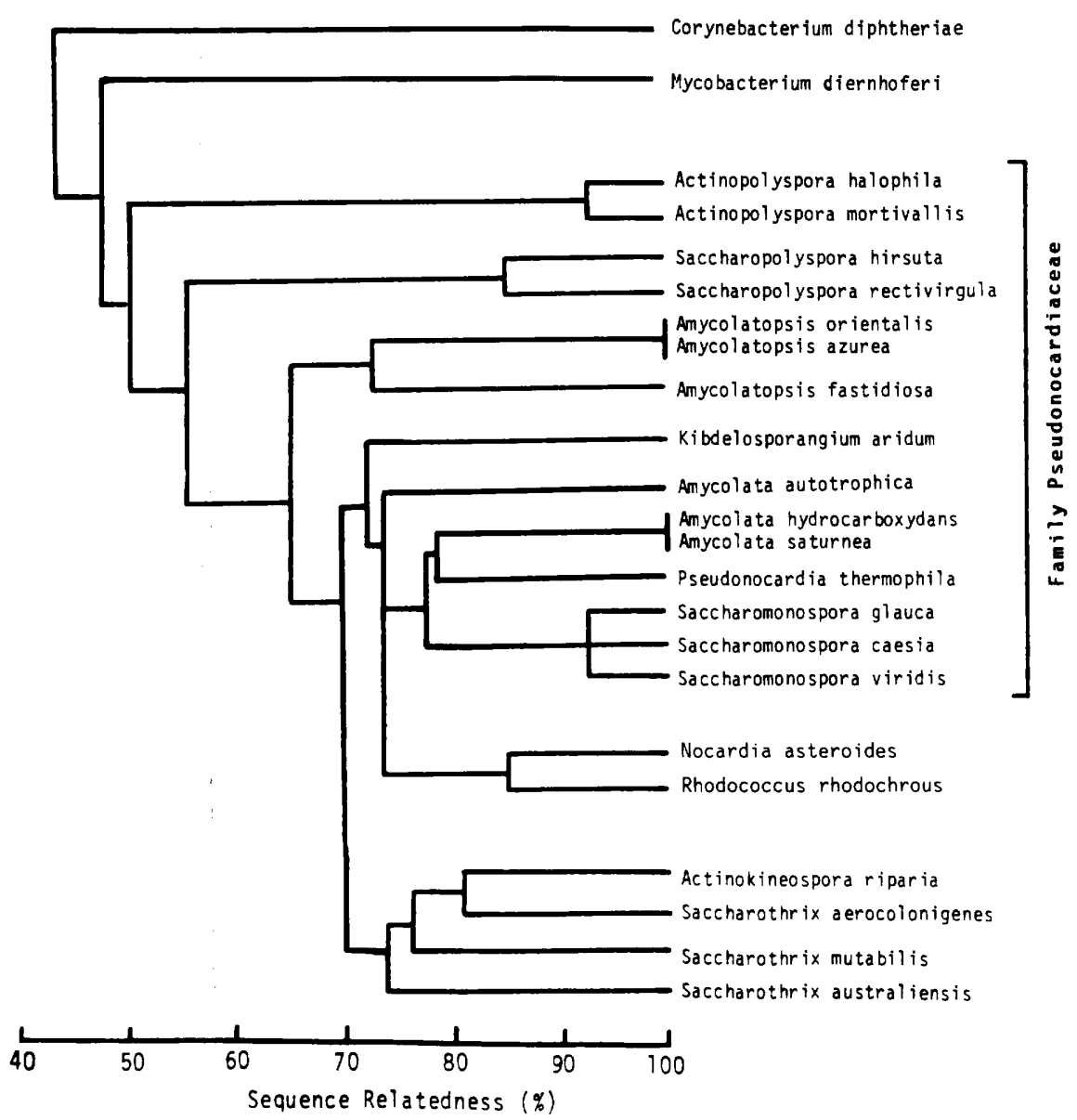

FIG. 2. Clustering of AT-L30 protein SAS values. The dendrogram was drawn from the data in Fig. 1.

Therefore, the low SAS values observed within the genus Saccharothrix (Fig. 2) signify that this genus contains phylogenetically distant species.

It is noteworthy that in agreement with the results of Warwick et al. (38), my study showed that the relationship between Amycolatopsis orientalis (the type species of the genus) and Amycolatopsis azurea was fully supported, while Amycolatopsis fastidiosa was separated by long branches from these two species (Fig. 2). Since these Amycolatopsis species share many phenotypic and chemical characteristics $(16,24)$, it is unlikely that Amycolatopsis fastidiosa is misclassified. Conceivably, the genus Amycolatopsis, as well as the genus Saccharothrix (see above), is a taxon which contains phylogenetically distant species.

It is interesting that Amycolata hydrocarboxydans and Amycolata saturnea are related more closely to Pseudonocardia thermophila than to Amycolata autotrophica (Fig. 2). Moreover, as presented in Table 1, these four organisms exhibit similar electrophoretic properties of AT-L30 proteins (REMs, 81.0 to $88.5)$. These results, together with other morphological and chemotaxonomic evidence $(6,19,22,24)$, fully support the proposal of Warwick et al. (38) that the genera Pseudonocardia and Amycolata be combined as a single genus.

The amino acid located at position 11 in Fig. 1 (position 12 in the numbering for Escherichia coli) has been shown to be an important signature for classification at the genus level, as demonstrated for the genera Escherichia, Bacillus, Staphylococcus, Thermoactinomyces, and Streptomyces $(29,31)$. However, variation in the amino acid at position 11 was found within a single genus of the family Pseudonocardiaceae (Fig. 1). Nevertheless, the presence of different amino acids at position 11 in the genera Saccharothrix and Actinokineospora (Fig. 1) can be taken in support of Actinokineospora as a distinct genus, since this position has never been occupied by glutamic acid in other actinomycete species examined so far.

Polyphasic taxonomy is the goal of modern procaryotic taxonomy, as stated by Wayne et al. (39) and Murray et al. (25). In these reports, polyphasism has been perceived as the integration of phylogenetic rRNA (or rDNA) sequence data with the distribution of chemotaxonomic and other phenotypic/epigenetic markers. Thus, it is widely believed that sequence analysis of rRNA molecules is the best means presently available for the construction of phylogenies. Several hundred variable positions are routinely compared in $16 \mathrm{~S}$ rRNA sequencing analyses. In contrast, less than 20 variable positions were used in the AT-L 30 sequencing analyses in this study. This rather small number of variable positions may be insufficient to accurately reflect phylogenetic relationships and may define the taxonomic limit of this technique. However, the ribosomal protein analysis, as demonstrated in the present and previous papers, can be helpful in reviewing microbial phylogeny on the basis of molecular data other than rRNA sequencing.

\section{ACKNOWLEDGMENTS}

This research was partly supported by a grant from Basic Research Core System. 
I thank Rieko Hayashi-Tadokoro for her skilled secretarial work.

\section{REFERENCES}

1. Bowen, T., E. Stackebrandt, M. Dorsch, and T. M. Embley. 1989. The phylogeny of Amycolata autotrophica, Kibdelosporangium aridum and Saccharothrix australiensis. J. Gen. Microbiol. 135:2529-2536.

2. Bowen, T., S. Warwick, J. Challans, and T. M. Embley. 1990. The use of ribosomal RNA sequences for the identification of members of the family Pseudonocardiaceae. Actinomycetes 1:49.

3. De Boer, L., L. Dijkhuizen, G. Grobben, M. Goodfellow, E. Stackebrandt, J. H. Parlett, D. Whitehead, and D. Witt. 1990. Amycolatopsis methanolica sp. nov., a facultatively methylotrophic actinomycete. Int. J. Syst. Bacteriol. 40:194-204.

4. Embley, T. M. 1992. The family Pseudonocardiaceae, p. 996-1027. In A. Balows, H. G. Trüper, M. Dworkin, W. Harder, and K.-H. Schleifer (ed.), The prokaryotes, 2nd ed. Springer-Verlag, New York.

5. Embley, T. M., M. Goodfellow, A. G. O'Donnell, D. Rose, and D. E. Minnikin. 1986. Chemical criteria in the classification of some mycolateless wall chemotype IV actinomycetes, p. 553-556. In G. Szabo, S. Biro, and M. Goodfellow (ed.), Biological, biochemical and biomedical aspects of actinomycetes. Akademiai Kiado, Budapest.

6. Embley, T. M., A. G. O'Donnell, J. Rostron, and M. Goodfellow. 1988. Chemotaxonomy of wall type IV actinomycetes which lack mycolic acids. J. Gen. Microbiol. 134:953-960.

7. Embley, T. M., J. Smida, and E. Stackebrandt. 1988. Reverse transcriptase sequencing of $16 \mathrm{~S}$ ribosomal RNA from Faenia rectivirgula, Pseudonocardia thermophila and Saccharopolyspora hirsuta, three wall type IV actinomycetes which lack mycolic acids. J. Gen. Microbiol. 134:961-966.

8. Embley, T. M., J. Smida, and E. Stackebrandt. 1988. The phylogeny of mycolate-less wall chemotype IV actinomycetes and description of Pseudonocardiaceae fam. nov. Syst. Appl. Microbiol. 11:44-52.

9. Embley, T. M., R. Wait, G. Dobson, and M. Goodfellow. 1987. Fatty acid composition in the classification of Saccharopolyspora hirsuta. FEMS Microbiol. Lett. 41:131-135.

10. Gochnauer, M. B., G. G. Leppard, P. Komaratat, M. Kates, T. Novitsky, and D. J. Kushner. 1975. Isolation and characterization of Actinopolyspora halophila, gen. et sp. nov., an extremely halophilic actinomycete. Can. J. Microbiol. 21:1500-1511.

11. Goodfellow, M., and T. Cross. 1984. Classification, p. 7-164. In M. Goodfellow, M. Mordarski, and S. T. Williams (ed.), The biology of actinomycetes. Academic Press, Ltd., London.

12. Hardy, S. J. S., C. G. Kurland, P. Voynow, and G. Mora. 1969. The ribosomal proteins of Escherichia coli. I. Purification of 30 S ribosomal proteins. Biochemistry 8:2897-2905.

13. Hasegawa, T. 1988. Actinokineospora: a new genus of the Actinomycetales. Actinomycetologica 2:31-45.

14. Henssen, A. 1989. Genus Pseudonocardia, p. 2376-2379. In S. T. Williams, M. E. Sharpe, and J. G. Holt (ed.), Bergey's manual of systematic bacteriology, vol. 4. The Williams \& Wilkins Co., Baltimore.

15. Henssen, A., C. Happach-kasan, B. Renner, and G. Vobis. 1983. Pseudonocardia compacta $\mathrm{sp}$. nov. Int. J. Syst. Bacteriol. 33:829-836.

16. Henssen, A., H. W. Kothe, and R. M. Kroppenstedt. 1987. Transfer of Pseudonocardia azurea and "Pseudonocardia fastidiosa" to the genus Amy colatopsis with emended species descriptions. Int. J. Syst. Bacteriol. 37:292295.

17. Kaltschmidt, E., and H. G. Wittmann. 1970. Ribosomal proteins. VII. Two-dimensional polyacrylamide gel electrophoresis for finger printing of ribosomal proteins. Anal. Biochem. 36:401-412.

18. Kimura, M. 1984. Proteins of the Bacillus stearothermophilus ribosome. J. Biol. Chem. 259:1051-1055.

19. Kothe, H. W., G. Vobis, R. M. Kroppenstedt, and A. Henssen. 1989. A taxonomic study of mycolateless, wall chemotype IV actinomycetes. Syst. Appl. Microbiol. 12:61-69.

20. Kroppenstedt, R. 1985. Fatty acid and menaquinone analysis of actinomycetes and related organisms, p. 173-199. In M. Goodfellow and D. E.
Minnikin (ed.), Chemical methods in bacterial systematics. Academic Press, Ltd., London.

21. Labeda, D. P., R. T. Testa, M. P. Lechevalier, and H. A. Lechevalier. 1984 Saccharothrix: a new genus of the Actinomycetales related to Nocardiopsis. Int. J. Syst. Bacteriol. 34:426-431.

22. Lechevalier, H. A. 1989. Nocardioform actinomycete, p. 2348-2350. In S. T. Williams, M. E. Sharpe, and J. G. Holt (ed.), Bergey's manual of systematic bacteriology, vol. 4. The Williams \& Wilkins Co., Baltimore.

23. Lechevalier, M. P., and H. A. Lechevalier. 1970. Chemical composition as a criterion in the classification of aerobic actinomycetes. Int. J. Syst. Bacteriol. 20:435-443.

24. Lechevalier, M. P., H. Prauser, D. P. Labeda, and J.-S. Ruan. 1986. Two new genera of nocardioform actinomycetes: Amycolata gen. nov. and Amycolatopsis gen. nov. Int. J. Syst. Bacteriol. 36:29-37.

25. Murray, R. G. E., D. J. Brenner, R. R. Colwell, P. De Vos, M. Goodfellow, P. A. D. Grimont, N. Pfenning, E. Stackebrandt, and G. A. Zavarzin. 1990 Report of the ad hoc committee on approaches to taxonomy within the proteobacteria. Int. J. Syst. Bacteriol. 40:213-215.

26. Ochi, K. 1989. Heterogeneity of ribosomal proteins among Streptomyces species and its application to identification. J. Gen. Microbiol. 135:26352642.

27. Ochi, K. 1992. Electrophoretic heterogeneity of ribosomal protein AT-L30 among actinomycete genera. Int. J. Syst. Bacteriol. 42:144-150.

28. Ochi, K. 1992. Polyacrylamide gel electrophoresis analysis of ribosomal protein: a new approach for actinomycete taxonomy. Gene 115:261-265.

29. Ochi, K. 1994. Phylogenetic diversity in the genus Bacillus and comparative ribosomal protein AT-L30 analyses of the genus Thermoactinomyces and relatives. Microbiology 140:2165-2171.

30. Ochi, K., K. Haraguchi, and S. Miyadoh. 1993. A taxonomic review of the genus Microbispora by analysis of ribosomal protein AT-L30. Int. J. Syst. Bacteriol. 43:58-62.

31. Ochi, K., and H. Hiranuma. 1994. A taxonomic review of the genera Kitasatosporia and Streptoverticillium by analysis of ribosomal protein ATL30. Int. J. Syst. Bacteriol. 44:285-292.

32. Ochi, K., and S. Miyadoh. 1992. Polyacrylamide gel electrophoresis analysis of ribosomal protein AT-L30 from an actinomycete genus. Streptosporangium. Int. J. Syst. Bacteriol. 42:151-155.

33. Ochi, K., S. Miyadoh, and T. Tamura. 1991. Polyacrylamide gel electrophoresis analysis of ribosomal protein AT-L30 as a novel approach to actinomycete taxonomy: application to the genera Actinomadura and $\mathrm{Mi}$ crotetraspora. Int. J. Syst. Bacteriol. 41:234-239.

34. Ochi, K., E. Satoh, and J. Shima. 1993. Amino acid sequence analysis of ribosomal protein AT-L30 from Streptosporangium corrugatum and Kibdelosporangium aridum. Syst. Appl. Microbiol. 16:13-16.

35. Ochi, K., and M. Yoshida. 1991. Polyacrylamide gel electrophoresis analysis of mycolateless wall chemotype VI actinomycetes. Int. J. Syst. Bacteriol. 41:402-405.

36. Ritter, E., and B. Wittmann-Liebold. 1975 . The primary structure of protein L30 from Escherichia coli ribosomes. FEBS Lett. 60:153-155.

37. Takeuchi, M., T. Nishii, and A. Yokota. 1992. Taxonomic significance of arabinose in the family Pseudonocardiaceae. Actinomycetologica 6:79-90.

38. Warwick, S., T. Bowen, H. McVeigh, and T. M. Embley. 1994. A phylogenetic analysis of the family Pseudonocardiaceae and the genera Actinokineospora and Saccharothrix with 16S rRNA sequences and a proposal to combine the genera Amycolata and Pseudonocardia in an emended genus Pseudonocardia. Int. J. Syst. Bacteriol. 44:293-299.

39. Wayne, L. G., D. J. Brenner, R. R. Colwell, P. A. D. Grimont, O. Kandler, M. I. Krichevsky, L. H. Moore, W. E. C. Moore, R. G. E. Murray, E. Stackebrandt, M. P. Starr, and H. G. Trüper. 1987. Report of the ad hoc committee on reconciliation of approaches to bacterial systematics. Int. J. Syst. Bacteriol. 37:463-464.

40. Yoshida, M., K. Matsubara, T. Kudo, and K. Horikoshi. 1991. Actinopolyspora mortivallis sp. nov., a moderately halophilic actinomycete. Int. J. Syst. Bacteriol. 41:15-20. 